\title{
Validated stability-indicating spectrofluorimetric methods for the determination of ebastine in pharmaceutical preparations
}

\author{
Fawzia Ibrahim, Mohie Khaled Sharaf El-Din, Manal Ibrahim Eid, Mary Elias Kamel Wahba*
}

\begin{abstract}
Two sensitive, selective, economic, and validated spectrofluorimetric methods were developed for the determination of ebastine (EBS) in pharmaceutical preparations depending on reaction with its tertiary amino group. Method I involves condensation of the drug with mixed anhydrides (citric and acetic anhydrides) producing a product with intense fluorescence, which was measured at $496 \mathrm{~nm}$ after excitation at $388 \mathrm{~nm}$.

Method (IIA) describes quantitative fluorescence quenching of eosin upon addition of the studied drug where the decrease in the fluorescence intensity was directly proportional to the concentration of ebastine; the fluorescence quenching was measured at $553 \mathrm{~nm}$ after excitation at $457 \mathrm{~nm}$. This method was extended to (Method IIB) to apply first and second derivative synchronous spectrofluorimetric method (FDSFS \& SDSFS) for the simultaneous analysis of EBS in presence of its alkaline, acidic, and UV degradation products.

The proposed methods were successfully applied for the determination of the studied compound in its dosage forms. The results obtained were in good agreement with those obtained by a comparison method. Both methods were utilized to investigate the kinetics of the degradation of the drug.
\end{abstract}

\section{Background}

Ebastine;(4'- tert.-butyl - 4-[4-(diphenylmethoxy) - piperidino] butyrophenone (Figure 1), is a potent long acting antihistaminic $\mathrm{H} 1$ receptor antagonist drugs [1]. Literature survey reveals that only high performance liquid chromatography was used for the estimation of ebastine in presence of its metabolites $[2,3]$.

Although chromatographic methods offer a high degree of specificity, yet they require large amount of high purity organic solvents and generate high amount of waste. Therefore, there is a need for an alternative substitute to these techniques for the routine quality control analysis of the concerned drug.

It is clear that there is a need for a method that is sensitive enough to monitor the drug level after therapeutic doses. Spectrofluorimetry by virtue of its high sensitivity meets this requirement. The proposed methods have some distinct advantages that render them promising substitutes for HPLC methods.

\footnotetext{
* Correspondence: marywahba2004@yahoo.com

Department of Analytical Chemistry, Faculty of Pharmacy, Mansoura University, Mansoura, 35516, Egypt
}

A number of organic acid anhydrides are capable of forming colored products with tertiary amines [4]; malonic, citric, and aconitic acids are representative examples. Aconitic acid however was found to be unsatisfactory as invariably a purple solution resulted on heating to dissolve the acid [5]. Tramadol, acebutolol and dothiepin were determined based on the condensation of the cited drugs with malonic and acetic acids [6] where the colored products were suitable for spectrophotometric and spectrofluorimetric measurements; while citric/acetic anhydrides were used for the spectrophotometric determination of nizatidine [7], and some $\mathrm{H} 1$ receptor antagonists [8] namely; cetirizine, fexofenadine, loratadine and acrivastine. Mixed anhydrides were also used for the colorimetric determination of epoxyamine formulations (resulting from the reaction of bisphenol A diglycidyl ether and $\mathrm{m}$-xylylenediamine) in a mixture of primary and secondary amines [9].

In spectrofluorimetric methods, high sensitivity and selectivity are generally expected. However, problems of selectivity can occur in multi-component analysis because of the overlap of their spectra that could be observed. Specificity is a particular problem in the determination of 


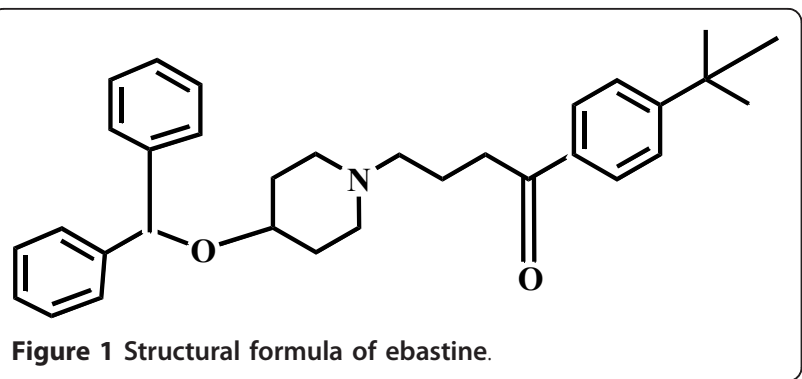

fluorescent drugs. Synchronous fluorescence spectroscopy (SFS) has been found to have several advantages [10], such as simple spectra, high selectivity, low interference, etc. Because of its sharp, narrow spectrum, SFS serves as a very simple, effective method of obtaining data for quantitative determination in a single measurement [11]. It has attracted the attention of many researchers and developed rapidly since it was firstly proposed by LIoyd [12].

Synchronous fluorescence spectroscopy techniques are classified according to different scanning modes of monochromators into constant wavelength, variety angle, and constant energy. At present, the constant wavelength method, in which a constant difference between the emission and excitation wavelengths is maintained, is used most extensively. The combination of SFS and derivative is more advantageous than differentiation of the conventional direct spectrofluorimetry in terms of sensitivity, because the amplitude of the derivative signal is inversely proportional to the bandwidth of the original spectrum [13].

Recently, derivative synchronous fluorometry (DSF) has been utilized for the determination of different mixtures in their co formulated dosage forms and biological fluids, such as metacycline and oxytetracycline [14], aspirin with caffeine [15] or aspirin with salicylic acid [16], diflunisal and salicylic acid [17], carvedilol and ampicillin [18], oxytetracycline in medicated premixes and feeds [19], cinnarizine with either domperidone or nicergoline [20,21], sulpiride and mebeverine hydrochloride [22] and benzo[a] pyrene in spiked fatty foods [23]. This technique was also applied for the determination of some drugs in the presence of their degradation products as in the case where sulpiride was determined in presence of its alkaline degradation product [24].

Other techniques mentioned in the literature for the determination of drugs in mixtures include: HPLC with diode array detection exemplified by the determination of colistin and tiamulin in liquid and solid medicated premixes [25], sulfamethazine and trimethoprim in liquid feed premixes [26]. HPLC employing pre-column derivatization was also applied as in the assay of colistin antibiotic in feeds after fluorimetric derivatization with phthaldialdehyde and 2-mercaptoethanol [27]. Organic solvent extraction or solid phase extraction followed by HPLC were also used such as determination of tiamulin in swine feeds [28] and sulfamethazine in milk [29] respectively. Furthermore, various assay procedures were mentioned for the determination of some drugs depending on the fact that changes in their chemical environment will modify their native spectra and allow their determination in mixtures, as illustrated by the high binding ability of oxytetracycline with some divalent cations that causes changes in its native fluorescence spectrum facilitating its determination in veterinary formulations [30].

The International Conference on Harmonization $(\mathrm{ICH})$ guidelines [31] entitled "stability testing of new drug substances and products" requires that stress testing be carried out to elucidate the inherent stability characteristics of the active substance. Susceptibility to alkaline, acidic, oxidative, and UV degradation are of the required tests. The present work is capable of presenting an efficient novel DSF method for the determination of EBS in the presence of its different degradation products, and to study the results kinetically so as to indicate that the method is a stability indicating one.

Up till now neither direct nor synchronous spectrofluorimetry has been reported for the analysis of ebastine alone or in presence of its degradation products.

\section{Experimental}

\section{Apparatus}

a) The fluorescence spectra and measurements were recorded using a Perkin Elmer LS 45 Luminescence Spectrometer equipped with a $150 \mathrm{~W}$ Xenon arc lamp. A $1 \mathrm{~cm}$ quartz cell was used. Derivative spectra were evaluated using Fluorescence Data Manager (FLDM) software, Perkin Elmer Buck i.e. FL WINLAB, version 400.02.

b) A Consort NV P901 pH meter

\section{Materials and reagents}

All reagents and solvents were of Analytical Reagent grade.

1) Ebastine (EBS); of purity $99.94 \%$ was kindly provided by Meivo Pharmaceutical Company, Cairo, Egypt.

2) Pharmaceutical preparations:

"Bastab ${ }^{\circledR}$ tablets (BN\#112038), labeled to contain 20 mg ebastine/tablet, Meivo Pharmaceutical Company, Cairo, Egypt.

"Evastine ${ }^{\circledR}$ syrup (BN\# 94634), labeled to contain $5 \mathrm{mg}$ ebastine/5 ml, Marcyrl Pharmaceutical Industries, El Obour City, Egypt.

3) Citric acid anhydride (CAA) was prepared as supersaturated solution by dissolving citric acid (Merck) in acetic anhydride (Prolabo) with the aid of sonication [8]

4) Eosin (Riedel-DE-Haen AG seeize-Hannover) $1.5 \times$ $10^{-3} \mathrm{M}$ aqueous solution. 
5) Mcliavain buffers ( $\mathrm{pH}$ ranging from 2-8) were prepared by mixing specific volumes of disodium hydrogen phosphate $(0.2 \mathrm{M})$ and citric acid $(0.2 \mathrm{M})$ [32].

6) Sodium hydroxide (0.1, 0.4 M solution), hydrochloric acid (0.1, 0.4 M solution), hydrogen peroxide ( $3 \% \mathrm{v} / \mathrm{v}$ solution); (BDH, Poole,UK).

5) Methanol (Aldrich)

\section{Standard solutions}

Stock solutions were prepared by dissolving $100.0 \mathrm{mg}$ of EBS in methanol and further diluted with the same solvent as appropriate. The standard solutions were stable for 7 days when kept in refrigerator.

\section{General Procedure}

\section{For method I}

Aliquots of standard solutions covering the concentration range of $0.1-1.0 \mu \mathrm{g} / \mathrm{ml}$ for EBS were transferred into a set of $10 \mathrm{ml}$ screw capped test tubes, evaporated to dryness in a boiling water bath, and cooled under tap water. Then $5.5 \mathrm{ml}$ of CAA reagent were added, and the test tubes were screwed up and heated in a boiling water bath for 35 minutes. The solutions were cooled and transferred quantitatively to $10 \mathrm{ml}$ volumetric flasks; diluted to the mark with distilled water and mixed well. The fluorescence intensity of the resulting solutions was measured at $496 \mathrm{~nm}$ after excitation at $388 \mathrm{~nm}$. A blank experiment was prepared simultaneously for each measurement. The corrected relative fluorescence intensity was plotted versus the final concentration of the drug $(\mu \mathrm{g} / \mathrm{ml})$ to get the calibration graph; alternatively, the corresponding regression equation was derived.

\section{For method IIA}

To a set of $10 \mathrm{ml}$ volumetric flasks, aliquots of ebastine standard solutions over the concentration range of 0.1$1.0 \mu \mathrm{g} / \mathrm{ml}$ were transferred, $1 \mathrm{ml}$ of $1.5 \times 10^{-3} \mathrm{M}$ eosin were added, followed by $2.5 \mathrm{ml}$ of mcliavain buffer $\mathrm{pH}$ 2.2 , the volume was completed to mark with distilled water and mixed well. The quenching of eosin fluorescence intensity was measured at $553 \mathrm{~nm}$ after excitation at $457 \mathrm{~nm}$.

\section{For method IIB}

After following the procedures mentioned in method IIA, The synchronous fluorescence spectra of the solutions were recorded by scanning both monochromators at $(\Delta$ $\lambda)=100,60$ or $40 \mathrm{~nm}$ in presence of alkaline, acidic, or UV degradation products respectively. A scan rate of 600 $\mathrm{nm} / \mathrm{min}$ using $10 \mathrm{~nm}$ excitation and emission windows was used. The first and second-derivative fluorescence spectra of EBS were derived from the normal synchronous spectra using FLDM software. For best resolution and smoothing 99 points were used. The fluorescence intensities of the first and second-derivative spectra were estimated at 421 and $453 \mathrm{~nm}$ respectively when EBS was determined in presence of its alkaline degradation product. When the drug was estimated in presence of its acidic degradation product the first and second-derivative spectra were determined at 431 and $419 \mathrm{~nm}$ respectively. On the other hand ebastine was determined at $437 \mathrm{~nm}$ and $458 \mathrm{~nm}$ using first and second-derivative techniques respectively. A blank experiment was performed simultaneously. The peak amplitude of either the first or the second derivative technique was plotted versus final concentration of the drug $(\mu \mathrm{g} / \mathrm{ml})$ to obtain the calibration graphs. Alternatively, the corresponding regression equations were derived.

\section{Procedure for determination of ebastine in presence of its degradation products}

Aliquot volumes of EBS standard stock solution $(400 \mu \mathrm{g} /$ $\mathrm{ml}$ ) were transferred into a series of $25 \mathrm{ml}$ volumetric flask to obtain a final concentration of $40 \mu \mathrm{g} / \mathrm{ml}$; the volume was completed with $0.1 \mathrm{M}$ sodium hydroxide or $0.1 \mathrm{M}$ hydrochloric acid to prepare the alkaline or acidic degradation product respectively. The solutions were left in a boiling water bath for 50 minutes (alkaline degradation) and for 30 minutes (acidic degradation). Regarding the UV degradation, the methanolic solution of EBS was exposed to Deuterium lamp in a cabinet distance of 15 $\mathrm{cm}$ for 9 hours. These time intervals were determined so as to follow the ICH guidelines [31] accomplishing 30\% degradation of the studied drug. Aliquot volumes of the degraded solutions were transferred to a series of $10 \mathrm{ml}$ volumetric flasks, neutralized with $0.1 \mathrm{M}$ hydrochloric acid or $0.1 \mathrm{M}$ sodium hydroxide for alkaline and acidic degradation respectively, and the steps described under procedure for method IIB were followed.

The peak amplitude of the first or the second derivative techniques were plotted versus the final concentration of the drug $(\mu \mathrm{g} / \mathrm{ml})$ to obtain the calibration graphs. Alternatively, the corresponding regression equations were derived

\section{Procedure for tablets}

Twenty tablets were weighed and pulverized. An accurately weighed quantity of the powder equivalent to contain $20 \mathrm{mg}$ of EBS was transferred into a small conical flask, extracted three successive times each with $30 \mathrm{ml}$ of methanol. The extract was filtered into $100 \mathrm{ml}$ volumetric flask. The conical flask was washed with few mls of methanol, transferred to the volumetric flask and completed to mark with the same solvent. Aliquots covering the concentration range were transferred either into $10 \mathrm{ml}$ screw capped test tubes (method I) or to 10 $\mathrm{ml}$ volumetric flasks (method IIA and IIB). The steps described under "General Procedures for method I, 
method IIA or method IIB" were followed. The nominal content of the tablets was determined either from the calibration graphs or from the corresponding regression equations.

\section{Procedure for syrup}

Aliquot volumes equivalent to $5 \mathrm{mg}$ of the studied drug were transferred into a $25 \mathrm{ml}$ volumetric flask, serial dilution was performed with methanol to obtain the working concentration range and the steps described under "General Procedure for method I, method IIA or method IIB" were followed. The nominal content of the syrup was determined either from the calibration graph or by using the corresponding regression equation.

\section{Procedure for preparation of degradation products}

For the kinetic study, $2.5 \mathrm{ml}$ of EBS standard solution $(400 \mu \mathrm{g} / \mathrm{ml})$ were transferred into a series of $25 \mathrm{ml}$ volumetric flasks to obtain a final concentration of $40 \mu \mathrm{g} / \mathrm{ml}$, $0.4 \mathrm{M}$ sodium hydroxide or $0.4 \mathrm{M}$ hydrochloric acid were added for method I. Regarding method II, $0.1 \mathrm{M}$ hydrochloric acid or $0.1 \mathrm{M}$ sodium hydroxide were used. The solutions were left in a thermostatically controlled water bath at different temperature settings $\left(50,60,70,80^{\circ} \mathrm{C}\right)$ for a fixed time interval (10 minutes). Aliquot volumes of the degraded solutions were transferred to a series of $10 \mathrm{ml}$ screw capped test tubes (method I) and neutralized with $0.4 \mathrm{M}$ hydrochloric acid or $0.4 \mathrm{M}$ sodium hydroxide for alkaline and acidic degradation respectively, alternatively the degraded solutions were transferred to $10 \mathrm{ml}$ volumetric flasks (method II) and neutralized with $0.1 \mathrm{M}$ hydrochloric acid or $0.1 \mathrm{M}$ sodium hydroxide for alkaline and acidic degradation respectively. The steps were completed as described under "General procedure". Log a/a-x versus time (minutes) was plotted to get the reaction rate constant and the half life time $t_{1 / 2}$.

\section{Results and discussion}

Ebastine forms a highly fluorescent reaction product upon reaction with citric acid anhydride (Figure 2). Citric acid anhydride is proposed to condense with ebastine producing an internal salt. The high $\mathrm{pK} a$ value of EBS [33] indicates that the rate of condensation reaction is dependent on the basicity of the tetriary amine. The fluorophore was formed instantaneously and remained stable for more than 90 minutes.

Ebastine and eosin $\mathrm{Y}$ react to form a complex that resulted in eosin $\mathrm{Y}$ fluorescence quenching. The maximum quenching wavelength was at $553 \mathrm{~nm}$ (Figure 3); this property was further extended to determine ebastine in presence of its degradation products. Figures 4ac illustrate the fluorescence spectra of the alkaline, acidic and UV degradation products of ebastine

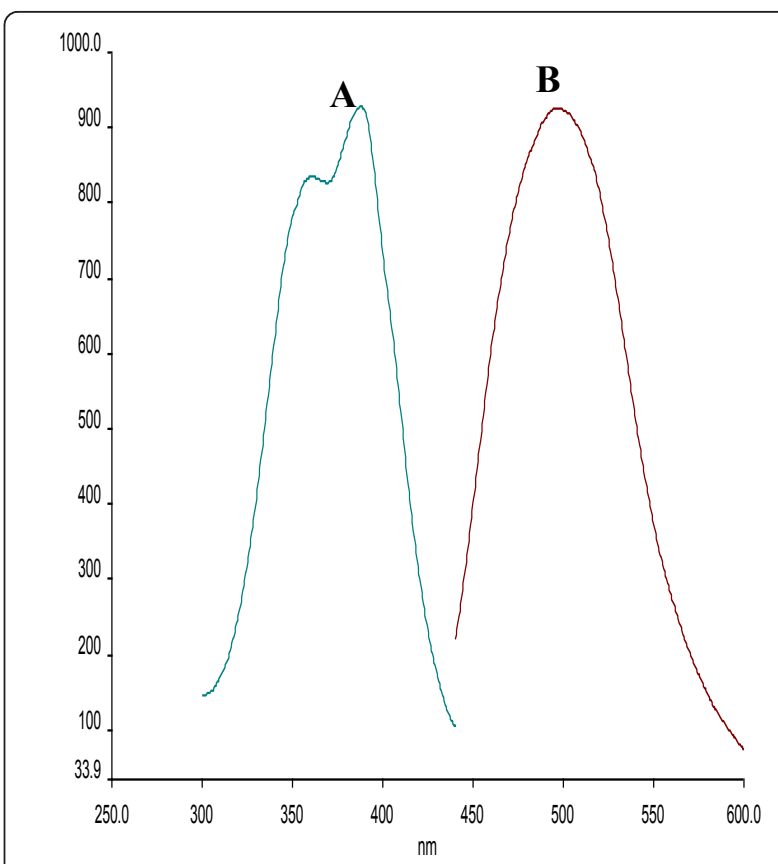

Figure 2 Fluorescence spectra of the EBS $(1 \mu \mathrm{g} / \mathrm{ml})$ - mixed anhydride condensation reaction product: Where $A$ and $B$ are the excitation and emission spectra respectively.

respectively with corresponding $\lambda_{\text {em }} / \lambda_{\text {ex }}$ of $(602 / 473 \mathrm{~nm}$, $576 / 474 \mathrm{~nm}$ and $561 / 472 \mathrm{~nm}$ ).

It is necessary to record first the normal synchronous fluorescence spectra of EBS in presence of its different degradation products to derive the first and second-

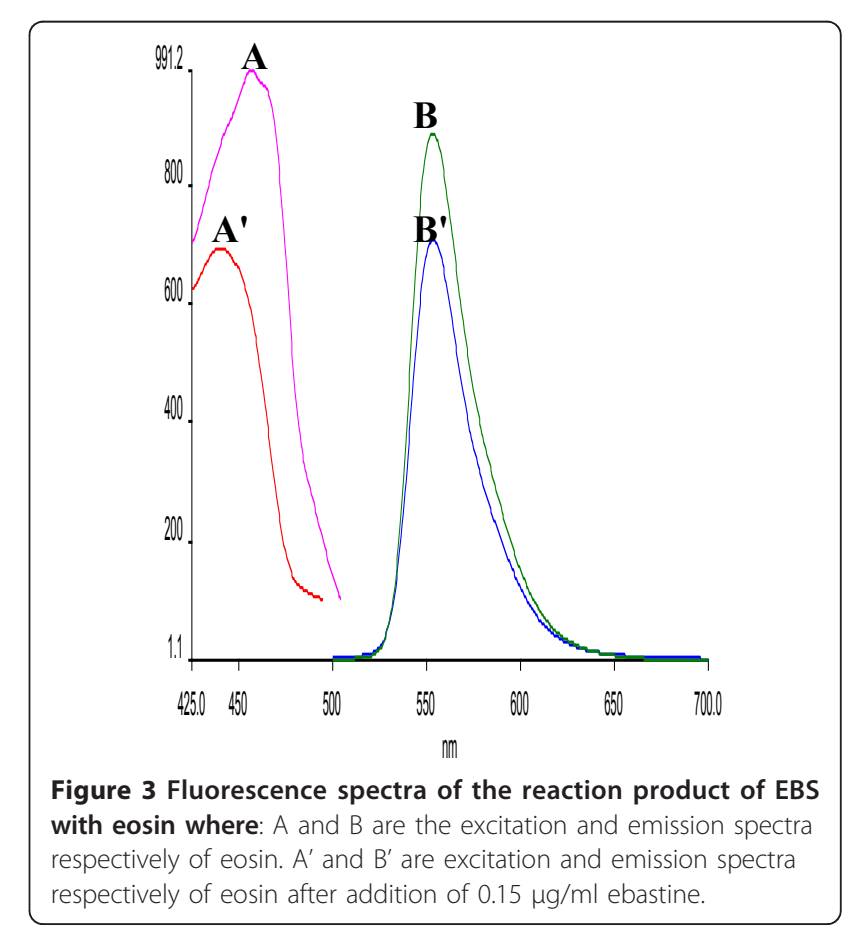




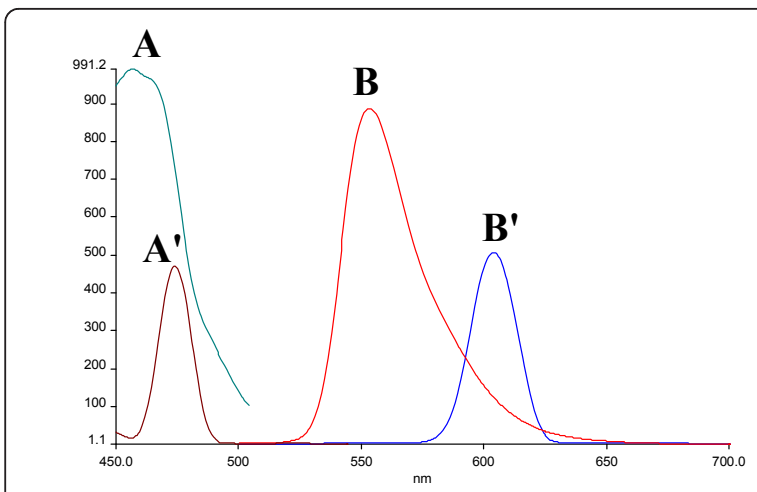

a

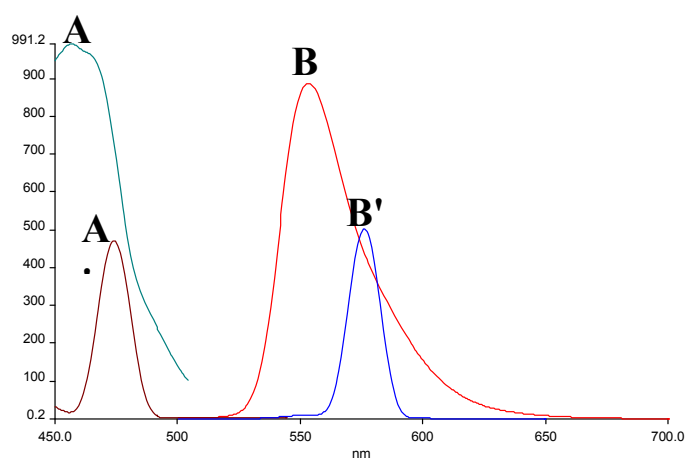

b

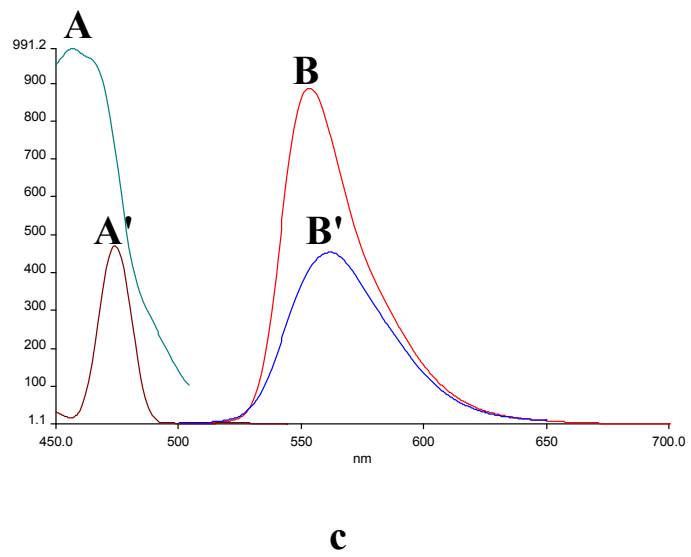

Figure 4 Fluorescence spectra of the degradation products of EBS through its reaction with eosin. Where $A$ and $B$ are the excitation and emission spectra respectively of eosin. $A^{\prime}$ and $B^{\prime}$ are excitation and emission spectra respectively of: 4a) Alkaline degradation product. 4b) Acidic degradation product. 4c) UV degradation product.

derivative synchronous spectra. The synchronous fluorescence spectra of EBS were recorded at $457 \mathrm{~nm}$ in presence of its alkaline, acidic and UV degradation products (Figures 5a-c) respectively. There is a great overlap of the spectra of the drug and its degradation products in normal synchronous spectroscopy; this encouraged us to perform first and second derivative synchronous fluorescence spectroscopy technique (FDSFS\&SDSFS) without prior extraction or separation step.

The fluorescence spectra of EBS and its different degradation products were separated entirely using FDSFS and SDSFS with a zero crossing technique of measurement. First and second derivative synchronous fluorescence spectra of EBS in presence of its alkaline degradation product (Figures 6a-b) show that ebastine could be separated at 421, $453 \mathrm{~nm}$ respectively. Similarly, entire separation of EBS in presence of its acidic degradation product was achieved at 431 and $419 \mathrm{~nm}$ using first and second derivative techniques respectively as shown in Figures 7a-b. While the FDSFS and SDSFS of the studied drug in the presence of its UV degradation product (Figures $8 \mathrm{a}-\mathrm{b}$ ) show that EBS could be determined at 437 and $458 \mathrm{~nm}$ respectively.

\section{Optimization of the reaction conditions for Method I}

The spectrofluorimetric properties of the formed fluorophore as well as the different experimental parameters affecting development and stability of the reaction product were carefully studied and optimized. Such factors were changed individually while the others were kept constant.

\section{Effect of volume of citric anhydride}

Keeping all the variables constant, it was found that increasing the volume of supersaturated solution of CAA resulted in a gradual increase in the relative fluorescence intensity of the reaction product up to $5 \mathrm{ml}$, after which it remained constant, therefore, $5.5 \pm 0.5 \mathrm{ml}$ was chosen for the study (Figure 9).

\section{Effect of reaction temperature}

The effect of reaction temperature was also studied keeping all the variables constant. The fluorescence intensity increased remarkably by increasing the temperature from 60 to $100^{\circ} \mathrm{C}$. Maximum fluorescence intensities were obtained through boiling of the reaction mixture. Hence, the reaction was carried out in a boiling water bath (Figure 10).

\section{Effect of boiling time}

It was found that increasing the time of boiling of the reaction mixture resulted in a gradual increase in the relative fluorescence intensity up to 30 minutes and remained constant till 40 minutes, after which it decreased gradually, therefore $35 \pm 5$ minutes of boiling was used during this approach (Figure 11).

\section{Effect of different diluting solvents}

Different diluting solvents were tested to choose the most suitable one for the formation of the reaction product, the investigated solvents included: water, methanol, acetonitrile, dimethylsulfoxide, dimethylformamide, and acetone. The highest fluorescence intensities were 


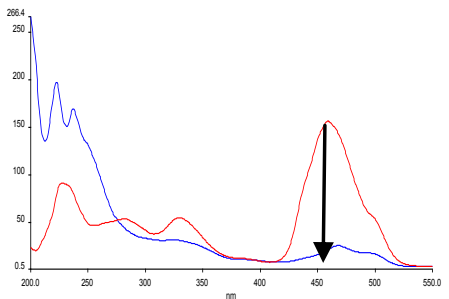

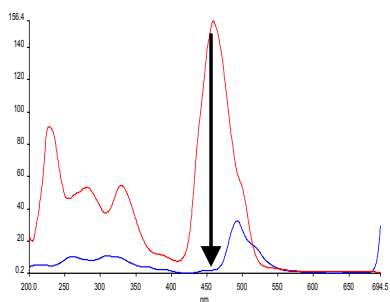

b

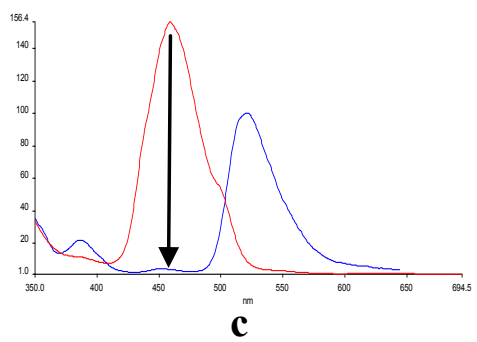

Figure 5 Synchronous fluorescence spectra of EBS at $\mathbf{4 5 7} \mathrm{nm}$ in presence of: a) Alkaline degradation product. b) Acidic degradation product. c) UV degradation product.
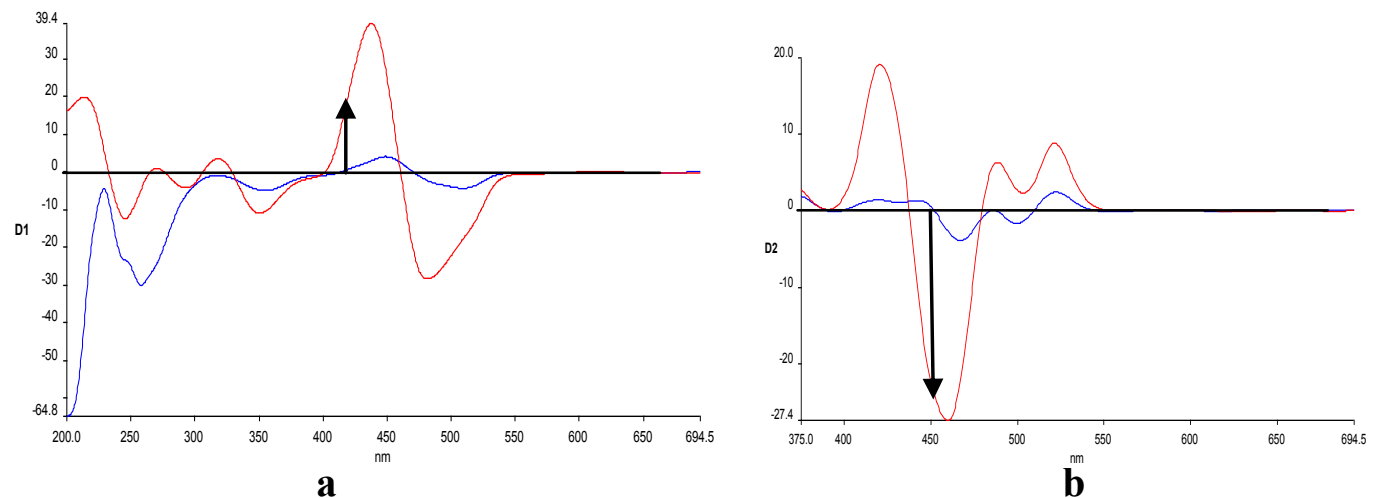

Figure 6 First and second derivative synchronous fluorescence spectra of EBS in presence of its alkaline degradation product. a) FDSFS of EBS at $421 \mathrm{~nm}$ in presence of its alkaline degradation product. b) SDSFS of EBS at 453nm in presence of its alkaline degradation product.
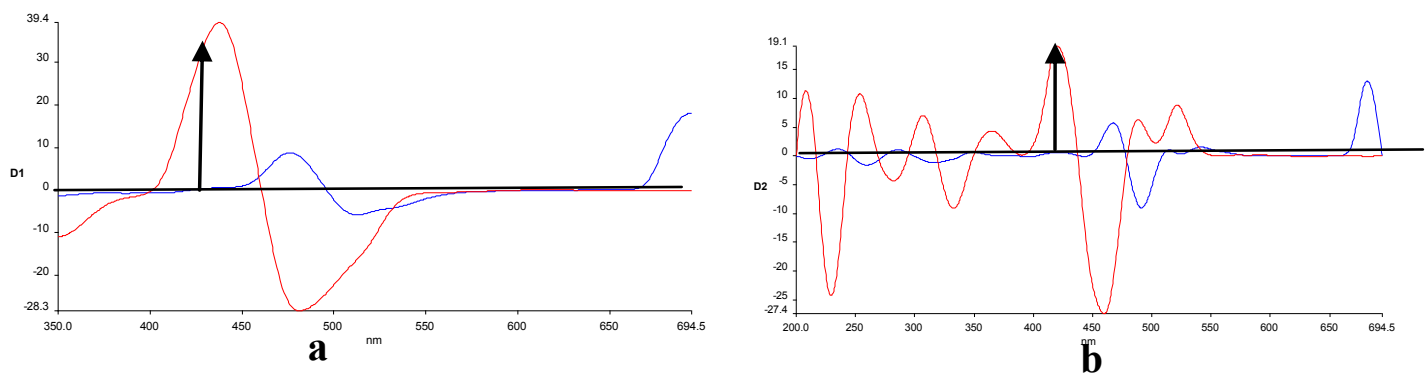

Figure 7 First and second derivative synchronous fluorescence spectra of EBS in presence of its acidic degradation product. a: FDSFS of EBS at $431 \mathrm{~nm}$ in presence of its acidic degradation product. b: SDSFS of EBS at $419 \mathrm{~nm}$ in presence of its acidic degradation product.
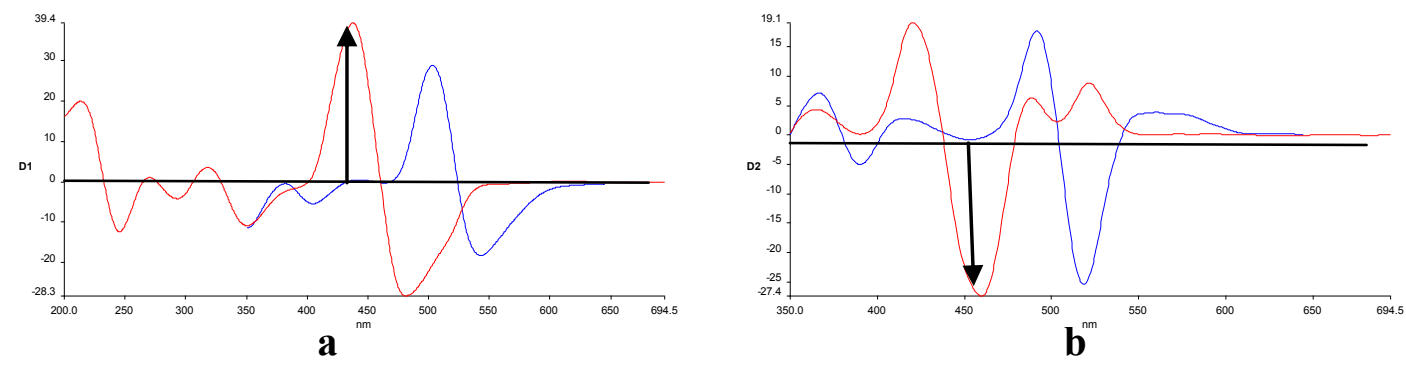

Figure 8 First and second derivative synchronous fluorescence spectra of EBS in presence of its UV degradation product. a) FDSFS of EBS at $437 \mathrm{~nm}$ in presence of its UV degradation product. b) SDSFS of EBS at $458 \mathrm{~nm}$ in presence of its UV degradation product. 


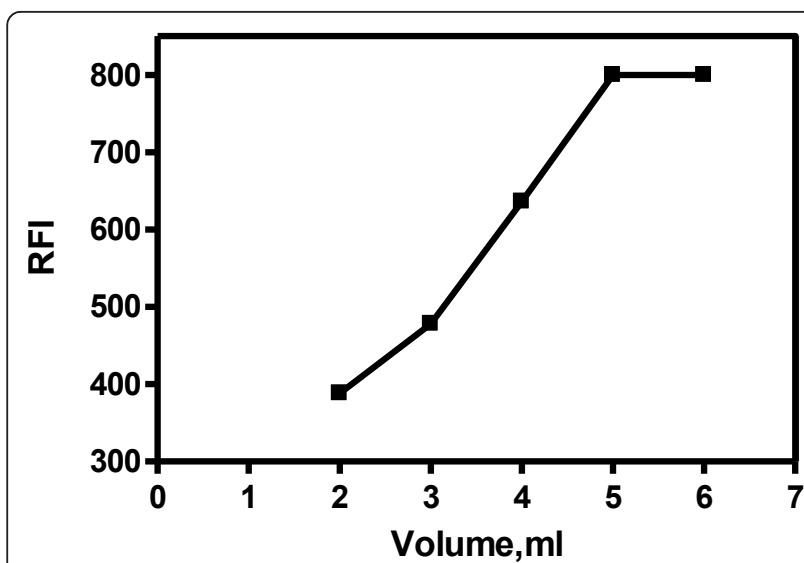

Figure 9 Effect of volume of CAA on the fluorescence intensity of the formed reaction product (EBS $=1 \mu \mathrm{g} / \mathrm{ml}$ ).

achieved upon using water. Moreover, its choice adds another advantage to the method. The results are demonstrated in Table 1.

\section{Optimization of the reaction conditions for Method IIA Effect of buffer $\mathrm{pH}$}

The effect of mcliavain buffer $\mathrm{pH}$ on the fluorescence quenching of eosin through its reaction with ebastine was studied over $\mathrm{pH}$ range of 2-8 keeping all the variables constant. It was found that maximum $\Delta \mathrm{F}$ was obtained at $\mathrm{pH}$ value of 2-2.5, after which gradual decrease in $\Delta \mathrm{F}$ was observed by increasing $\mathrm{pH}$ value (Figure 12), hence mcliavain buffer of pH 2.2 was used in this study.

\section{Effect of buffer volume}

The effect of mcliavain buffer volume $(\mathrm{pH} 2.2)$ on the fluorescence quenching was also investigated. Gradual increase in $\Delta \mathrm{F}$ values was obtained by increasing the volume of the buffer up to $2 \mathrm{ml}$, after which, the $\Delta \mathrm{F}$ values remained constant (Figure 13). Therefore, $2.5 \mathrm{ml}$ of mcliavain buffer $\mathrm{pH} 2.2$ was used throughout this method.

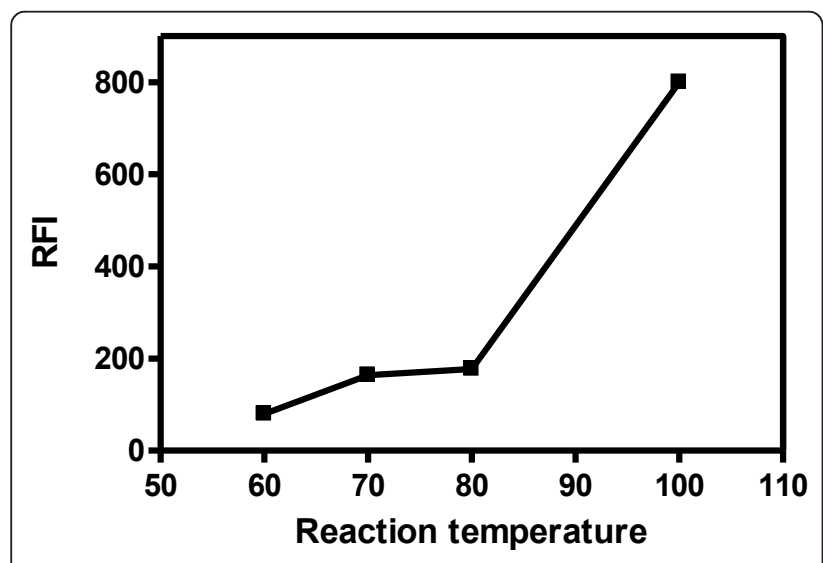

Figure 10 Effect of reaction temperature on the fluorescence intensity of the formed reaction product (EBS $=1 \mu \mathrm{g} / \mathrm{ml}$ ).

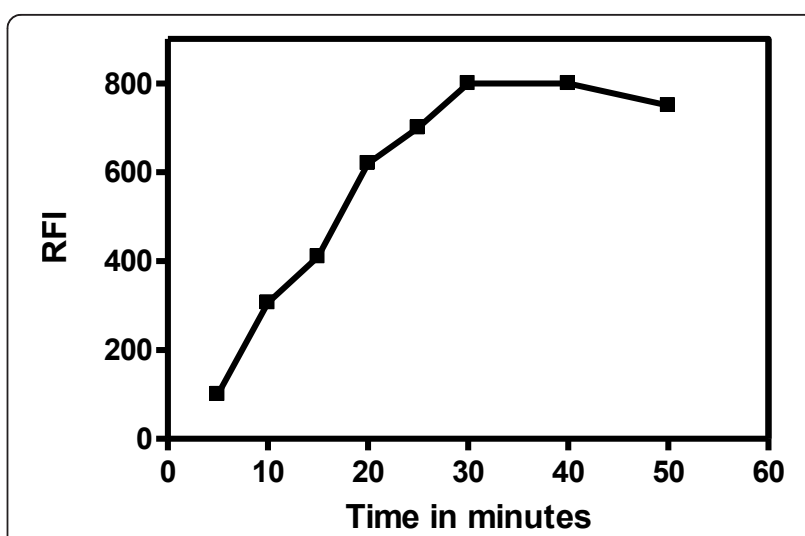

Figure 11 Effect of boiling time on the fluorescence intensity of the formed reaction product (EBS $=1 \mu \mathrm{g} / \mathrm{ml}$ ).

\section{Effect of different diluting solvents}

Different diluting solvents were tested to choose the most suitable one for maximum fluorescence quenching. The highest $\Delta \mathrm{F}$ values were achieved upon using water. The results are demonstrated in Table 1.

\section{Optimization of the reaction conditions for Method IIB}

The same reaction conditions concerning method IIA were applied; in addition effect of $\Delta \lambda$ was also investigated as follows:

\section{Selection of optimum $\Delta \lambda$}

The synchronous fluorescence spectra of EBS in presence of its different degradation products were recorded using different $\Delta \lambda$. The optimum $\Delta \lambda$ value is very important for performing the synchronous fluorescence scanning technique concerning resolution, sensitivity, and features. It can directly influence spectral shape, bandwidth, and signal value. For this reason, a wide range of $\Delta \lambda(40,60,80,100$, and $120 \mathrm{~nm})$ was examined. Therefore, $\Delta \lambda$ of 100,60 or $40 \mathrm{~nm}$ were chosen as optimal for separation of EBS in presence of its alkaline, acidic or UV degradation products respectively, since it resulted in distinct well separated peaks, with good shape, and highest SFI values.

Table 1 Effect of different diluting solvents on the fluorescence intensity (method I) or $\Delta F$ (method IIA)

\begin{tabular}{ccc}
\hline Diluting solvent & \multicolumn{2}{c}{ Proposed method } \\
\hline & Method I & Method IIA \\
\hline Water & 700 & 690 \\
\hline Methanol & 684 & 450 \\
\hline Acetonitrile & 412 & 430 \\
\hline Dioxane & 304 & 389 \\
\hline Dimethylformamide & 122 & 230 \\
\hline Acetone & 30 & 150 \\
\hline
\end{tabular}

Ebastine $=1 \mu \mathrm{g} / \mathrm{ml}$. 


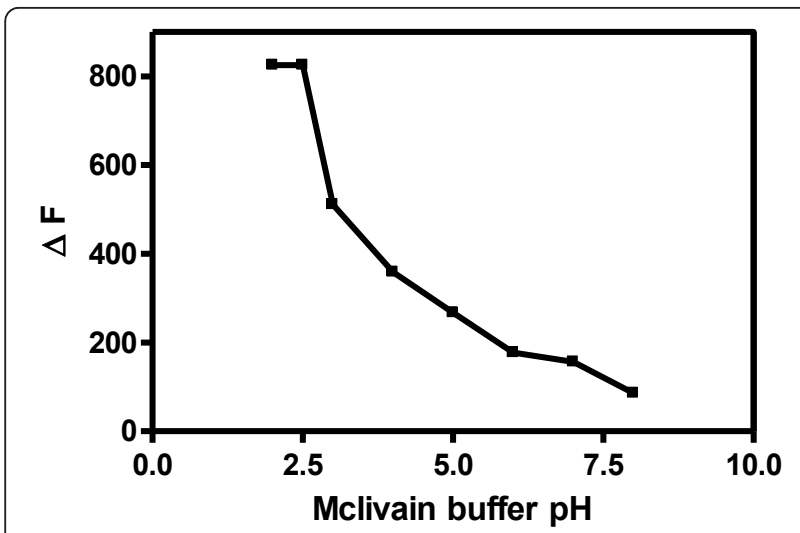

Figure 12 Effect of buffer $\mathrm{pH}$ on fluorescence quenching of eosin by EBS $(E B S=1 \mu \mathrm{g} / \mathrm{ml})$.

\section{Analytical performance and application}

The relative fluorescence intensity, $\Delta F$, or peak amplitude (by FDSFS and SDSFS) - concentration plots for ebastine by method I, method IIA, and method II B respectively were linear over the concentration ranges cited in Tables 2 and 3. The linearity of the calibration curves is validated by the high value of the correlation coefficient and value of the intercept which is close to zero.

\section{Sensitivity}

Detection limit (LOD) is the lowest concentration of the drug that can be detected, but not necessarily quantitated, under the stated experimental conditions. The limit of detection is generally quoted as the concentration yielding a signal-to-noise ratio of 3:1 [34] and is confirmed by analyzing a number of samples near this value using the following equation:

The signal - to - noise ratio $\mathrm{s}=\mathrm{H} / \mathrm{h}$

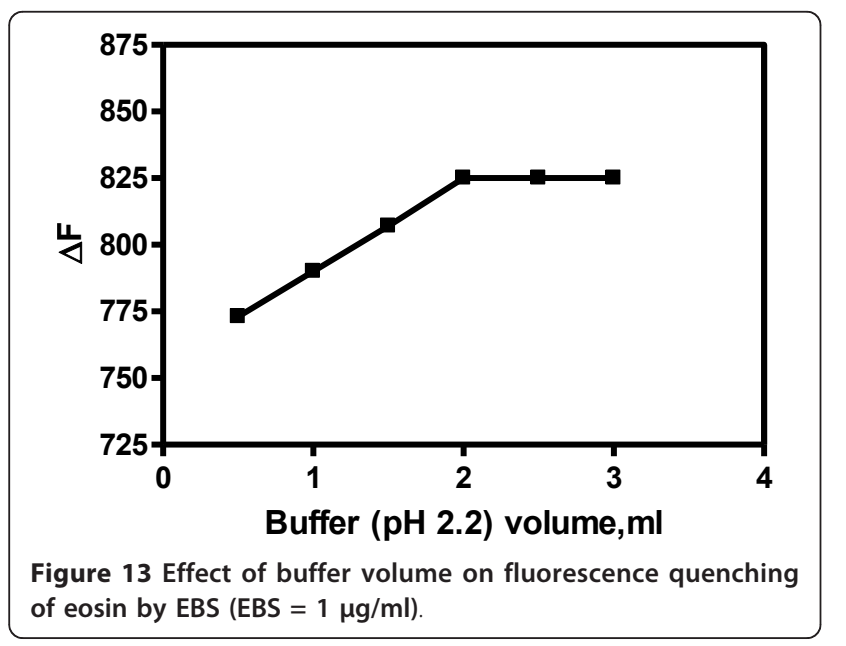

Table 2 Performance data of method I and method IIA

\begin{tabular}{lcc}
\hline Parameter & \multicolumn{2}{c}{ Value } \\
\hline & $\begin{array}{c}\text { Method } \\
\text { I }\end{array}$ & $\begin{array}{c}\text { Method } \\
\text { IIA }\end{array}$ \\
\hline Concentration range $(\boldsymbol{\mu g} / \mathrm{ml})$ & $0.1-1.0$ & $0.1-1.0$ \\
\hline $\mathbf{L O D}(\boldsymbol{\mu g} / \mathrm{ml})$ & $\mathbf{0 . 0 2 6}$ & $\mathbf{0 . 0 2 1}$ \\
\hline $\mathbf{L O Q}(\boldsymbol{\mu g} / \mathrm{ml})$ & $\mathbf{0 . 0 6 6}$ & $\mathbf{0 . 0 4 2}$ \\
\hline Correlation coefficient $(\mathbf{r})$ & 0.9998 & 0.9999 \\
\hline Slope & 0.76 & 0.83 \\
\hline Intercept & -0.13 & 1.13 \\
\hline $\mathbf{S}_{\mathbf{y} / \mathbf{x}, \text { Standard deviation of the residuals }}$ & 0.05 & 1.54 \\
\hline $\mathbf{S}_{\mathbf{a}}$ Standard deviation of the intercept of the & 0.001 & 0.77 \\
regression line & & \\
\hline $\begin{array}{l}\mathbf{S}_{\mathbf{b}} \text {, Standard deviation of the slope of the } \\
\text { regression line }\end{array}$ & 0.03 & 0.002 \\
\hline
\end{tabular}

Where $\mathrm{H}=$ height of the spectrum corresponding to the drug.

$\mathrm{h}=$ absolute value of the largest noise fluctuation from the baseline of the spectrum of a blank solution.

While the limit of quantification (LOQ); is the lowest concentration of the analyte that can be determined with acceptable precision and accuracy. It is quoted as the concentration yielding a signal-to-noise ratio of 10 : 1 and is confirmed by analyzing a number of samples near this value [34].The calculated values are listed in Tables 2 and 3.

\section{Validation of the proposed methods}

The proposed methods were tested for linearity, selectivity, accuracy and precision. Using the above spectrofluorimetric methods, linear regression equations were obtained. The regression plots showed that there was a linear dependence of the fluorescence intensity values, $\Delta \mathrm{F}$ values, or peak amplitude values on the concentration of the drug over the ranges cited in Tables 2 and 3. The validity of the proposed methods was evaluated by statistical analysis of the regression data regarding the standard deviation of the residual $\left(\mathrm{S}_{\mathrm{y} / \mathrm{x}}\right)$, the standard deviation of the intercept $\left(\mathrm{S}_{\mathrm{a}}\right)$, and standard deviation of the slope $\left(\mathrm{S}_{\mathrm{b}}\right)$ [35]. The results are shown in Tables 2 and 3 . The small values of the figures point to the low scattering of the points around the calibration graphs and high precision of the proposed methods.

\section{Accuracy}

The accuracy of the proposed methods was evaluated by analyzing standard solutions of ebastine. The results obtained by the proposed methods were favorably compared with those obtained by the comparison method [3].

Statistical analysis [35] of the results obtained by the proposed and comparison methods using student's t-test and variance ratio F- test, showed no significant difference 
Table 3 Performance data of method IIB

\begin{tabular}{|c|c|c|c|c|c|c|}
\hline \multirow[t]{2}{*}{ Parameter } & \multicolumn{2}{|c|}{ Alkaline degradation } & \multicolumn{2}{|c|}{ Acidic degradation } & \multicolumn{2}{|c|}{ UV degradation } \\
\hline & $\begin{array}{c}\text { First } \\
\text { derivative }\end{array}$ & $\begin{array}{c}\text { Second } \\
\text { derivative }\end{array}$ & $\begin{array}{c}\text { First } \\
\text { derivative }\end{array}$ & $\begin{array}{c}\text { Second } \\
\text { derivative }\end{array}$ & $\begin{array}{c}\text { First } \\
\text { derivative }\end{array}$ & $\begin{array}{c}\text { Second } \\
\text { derivative }\end{array}$ \\
\hline Concentration range $(\mu \mathrm{g} / \mathrm{ml})$ & \multicolumn{6}{|c|}{$0.1-1.0$} \\
\hline $\operatorname{LOD}(\mu \mathrm{g} / \mathrm{ml})$ & 0.022 & 0.013 & 0.033 & 0.043 & 0.014 & 0.028 \\
\hline LOQ $(\mu \mathrm{g} / \mathrm{ml})$ & 0.054 & 0.044 & 0.052 & 0.063 & 0.047 & 0.052 \\
\hline Correlation coefficient (r) & 0.9999 & 0.9994 & 0.9999 & 0.9998 & 0.9995 & 0.9996 \\
\hline Slope & 0.36 & 0.201 & 0.202 & 0.301 & 0.16 & 0.203 \\
\hline Intercept & 0.89 & 1.18 & -1.11 & 0.97 & 0.96 & 1.12 \\
\hline $\mathbf{S}_{\mathbf{y} / \mathbf{x}}$, Standard deviation of the residuals & 1.17 & 1.55 & 0.77 & 1.28 & 1.19 & 1.39 \\
\hline $\begin{array}{l}\mathbf{S}_{\mathbf{a}} \text {, Standard deviation of the intercept of the } \\
\text { regression line }\end{array}$ & -0.43 & -0.44 & 0.58 & -0.34 & 0.74 & 0.68 \\
\hline $\begin{array}{l}\mathbf{S}_{\mathbf{b}} \text {, Standard deviation of the slope of the } \\
\text { regression line }\end{array}$ & $1.46 \times 10^{-3}$ & $1.94 \times 10^{-3}$ & $9.59 \times 10^{-4}$ & $1.59 \times 10^{-3}$ & $1.56 \times 10^{-3}$ & $1.82 \times 10^{-3}$ \\
\hline
\end{tabular}

between the performance of the two methods regarding the accuracy and precision, respectively (Tables 4,5 ).

The proposed methods were evaluated by studying the accuracy as percent relative error and precision as percent relative standard deviation (RSD\%); the results are summarized in Tables 4, 5 .

\section{Precision}

Repeatability The repeatability was evaluated through analysis of different concentrations of the studied drug in pure or in dosage forms on 4 successive times. The mean percentage recoveries listed in Table 6 indicate the high precision of the proposed methods.

Intermediate precision It was performed through repeated analysis of variable concentrations of EBS either per se or in dosage forms on four successive days. The results are abridged in Table 6.

Robustness of the method The robustness of the methods adopted was demonstrated by the consistency of the relative fluorescence intensity, $\Delta \mathrm{F}$, or peak amplitude values with the deliberately minor changes in the experimental parameters such as: volume of CAA (5.5 \pm
$0.5 \mathrm{ml})$, boiling time (30 $\pm 5 \mathrm{~min}$.), buffer $\mathrm{pH}(2.2 \pm 0.2)$ and buffer volume $(2.5 \pm 0.5)$ which did not greatly affect the results obtained.

\section{Pharmaceutical applications}

The proposed methods were successfully applied to the determination of ebastine in its dosage forms. The results are summarized in Tables 7 and 8 . No interference from the sample matrix was observed, the results were found to be in good agreement with the labeled amount.

\section{Stability study}

The proposed methods are based mainly on the reaction between citric acid anhydride and eosin with the tertiary amino group of ebastine. Therefore, degradation was attained upon induced alkaline degradation using sodium hydroxide (0.4 M for method I, 0.1 M for method II), acidic degradation using hydrochloric acid $(0.4 \mathrm{M}, 0.1 \mathrm{M}$ for methods I and II respectively) and oxidative degradation using $3 \%$ hydrogen peroxide. Upon alkaline and acidic

Table 4 Determination of ebastine in its pure form using method I

\begin{tabular}{|c|c|c|c|c|}
\hline Parameter & Amount taken $(\mu \mathrm{g} / \mathrm{ml})$ & Amount found $(\mu \mathrm{g} / \mathrm{ml})$ & $\%$ Recovery & Comparison method ${ }^{3}, \%$ Recovery \\
\hline & 0.1 & 0.099 & 99.0 & 100.62 \\
\hline & 0.2 & 0.199 & 99.90 & 99.15 \\
\hline & 0.3 & 0.298 & 99.33 & 99.34 \\
\hline & 0.5 & 0.502 & 100.40 & \\
\hline & 0.7 & 0.706 & 100.86 & \\
\hline & 0.8 & 0.799 & 99.88 & \\
\hline & 1.0 & 1.005 & 100.5 & \\
\hline $\mathrm{X}^{-} \pm \mathrm{SD}$ & & & $99.98 \pm 0.66$ & $99.70 \pm 0.79$ \\
\hline Student's $\mathrm{t}$ test & & & $0.33(1.94)^{*}$ & \\
\hline Variance ratio $\mathrm{F}$ test & & & $1.4(5.14)^{*}$ & \\
\hline
\end{tabular}

*Figures between parenthesis are tabulated $t$ and $F$ values at $P=0.05^{35}$. 
Table 5 Determination of ebastine in its pure form using method IIB

\begin{tabular}{|c|c|c|c|c|c|c|c|c|}
\hline \multirow{2}{*}{$\begin{array}{c}\text { Parameter } \\
\begin{array}{c}\text { Ebastine in presence of its alkaline } \\
\text { degradation product }\end{array}\end{array}$} & \multirow[t]{2}{*}{$\begin{array}{l}\text { Amount taken } \\
(\mu \mathrm{g} / \mathrm{ml})\end{array}$} & \multicolumn{3}{|c|}{$\begin{array}{l}\text { Amount found } \\
(\mu \mathrm{g} / \mathrm{ml})\end{array}$} & \multicolumn{3}{|c|}{ \%Recovery } & \multirow{2}{*}{$\begin{array}{c}\text { Comparisor } \\
\text { method }^{3}\end{array}$} \\
\hline & & SFS & FDSFS & SDSFS & SFS & FDSFS & SDSFS & \\
\hline & 0.1 & 0.099 & 0.101 & 0.1003 & 99.11 & 100.82 & 100.33 & 100.62 \\
\hline & 0.2 & 0.198 & 0.201 & 0.201 & 99.22 & 100.53 & 100.45 & 99.15 \\
\hline & 0.3 & 0.301 & 0.298 & 0.301 & 100.33 & 99.33 & 100.27 & 99.34 \\
\hline & 0.5 & 0.498 & 0.503 & 0.495 & 99.62 & 100.62 & 99.05 & \\
\hline & 0.7 & 0.704 & 0.694 & 0.706 & 100.57 & 99.14 & 100.86 & \\
\hline & 0.8 & 0.806 & 0.793 & 0.795 & 100.75 & 99.13 & 99.38 & \\
\hline & 1.0 & 0.994 & 1.01 & 0.999 & 99.46 & 100.92 & 99.93 & \\
\hline$X^{-} \pm S D$ & & & & & $99.87 \pm 0.67$ & $100.07 \pm 0.83$ & $100.04 \pm 0.63$ & $99.70 \pm 0.79$ \\
\hline Student's $t$ test & & & & & $0.96(1.94)$ & $0.94(1.94)$ & $0.78(1.94)$ & \\
\hline Variance ratio $F$ test & & & & & $1.39(5.14)$ & $1.1(5.14)$ & $1.57(5.14)$ & \\
\hline \multirow{7}{*}{$\begin{array}{l}\text { Ebastine in presence of its acidic } \\
\text { degradation product }\end{array}$} & 0.1 & 0.099 & 0.101 & 0.099 & 99.15 & 100.62 & 99.44 & 100.62 \\
\hline & 0.2 & 0.201 & 0.198 & 0.201 & 100.62 & 99.34 & 100.23 & 99.15 \\
\hline & 0.3 & 0.301 & 0.299 & 0.302 & 100.37 & 99.72 & 100.67 & 99.34 \\
\hline & 0.5 & 0.499 & 0.502 & 0.501 & 99.72 & 100.33 & 100.15 & \\
\hline & 0.7 & 0.697 & 0.704 & 0.698 & 99.63 & 100.66 & 99.77 & \\
\hline & 0.8 & 0.807 & 0.796 & 0.799 & 100.84 & 99.46 & 99.81 & \\
\hline & 1.0 & 0.1003 & 0.1003 & 0.995 & 100.25 & 100.27 & 99.47 & \\
\hline $\mathrm{X}^{-} \pm \mathrm{SD}$ & & & & & $\begin{array}{c}100.08 \pm \\
0.61\end{array}$ & $100.06 \pm 0.54$ & $99.93 \pm 0.44$ & $99.70 \pm 0.79$ \\
\hline Student's $t$ test & & & & & $0.36(1.94)$ & $0.36(1.94)$ & $0.39(1.94)$ & \\
\hline Variance ratio $\mathrm{F}$ test & & & & & $1.68(5.14)$ & $2.14(5.14)$ & $3.22(5.14)$ & \\
\hline \multirow{7}{*}{$\begin{array}{c}\text { Ebastine in presence of its UV } \\
\text { degradation product }\end{array}$} & 0.1 & 0.1001 & 0.099 & 0.101 & 100.12 & 99.77 & 100.73 & 100.62 \\
\hline & 0.2 & 0.201 & 0.201 & 0.201 & 100.64 & 100.52 & 100.44 & 99.15 \\
\hline & 0.3 & 0.299 & 0.302 & 0.301 & 99.87 & 100.67 & 100.21 & 99.34 \\
\hline & 0.5 & 0.497 & 0.497 & 0.496 & 99.47 & 99.28 & 99.22 & \\
\hline & 0.7 & 0.694 & 0.698 & 0.695 & 99.19 & 99.73 & 99.34 & \\
\hline & 0.8 & 0.803 & 0.805 & 0.797 & 100.32 & 100.66 & 99.64 & \\
\hline & 1.0 & 1.006 & 1.005 & 1.003 & 100.55 & 100.49 & 100.29 & \\
\hline $\mathrm{X}^{-} \pm \mathrm{SD}$ & & & & & $\begin{array}{c}100.02 \pm \\
0.54\end{array}$ & $100.16 \pm 0.56$ & $99.98 \pm 0.58$ & $99.70 \pm 0.79$ \\
\hline Student's $t$ test & & & & & $0.94(1.94)$ & $0.42(1.94)$ & $0.44(1.94)$ & \\
\hline Variance ratio $\mathrm{F}$ test & & & & & $2.14(5.14)$ & $1.99(5.14)$ & $1.86(5.14)$ & \\
\hline
\end{tabular}

degradation of the drug, the relative fluorescence readings or $\Delta \mathrm{F}$ values decreased gradually with time, thus indicating that the proposed methods are stability indicating ones. However, the proposed methods did not indicate the peroxide degradation of ebastine, and this may be due to the formation of the N-oxide derivative of the drug which is not susceptible to react with either CAA or eosin owing to the blocking of the tertiary amino group.

Both alkaline and acidic degradation were found to be temperature dependant as presented by the acidic degradation for method I (Figure 14). The first order degradation rate constant and the half life time at each temperature were calculated (Table 9). Plotting log $\mathrm{K}_{\mathrm{obs}}$ values versus $1 / \mathrm{T}$, the Arhenius plots were obtained and exemplified by Figure 15. The activation energy for each type of degradation was also calculated.

Upon exposure of methanolic solution of the concerned drug to Deuterium lamp with a wavelength of $254 \mathrm{~nm}$ at a distance of $15 \mathrm{~cm}$ in a cabinet for different time intervals, and then the studied methods were applied, it was found that EBS decomposed by $22,19 \%$ applying method I and method II respectively. 
Table 6 Validation of the proposed methods for the determination oof ebastine in pure and dosage forms

\begin{tabular}{|c|c|c|c|c|}
\hline \multirow[t]{2}{*}{ Preparation } & \multicolumn{2}{|c|}{ Repeatability, \% Found } & \multicolumn{2}{|c|}{ Intermediate precision, \% Found } \\
\hline & Method I & Method II & Method I & Method II \\
\hline \multirow[t]{5}{*}{ Ebastine pure form } & Ebastine $(0.5 \mu \mathrm{g} / \mathrm{ml})$ & Ebastine $(0.1 \mu \mathrm{g} / \mathrm{ml})$ & Ebastine $(0.3 \mu \mathrm{g} / \mathrm{ml})$ & Ebastine $(0.7 \mu \mathrm{g} / \mathrm{ml})$ \\
\hline & 99.62 & 100.25 & 100.66 & 99.54 \\
\hline & 99.24 & 100.65 & 100.06 & 99.35 \\
\hline & 100.65 & 100.87 & 100.97 & 100.15 \\
\hline & 100.25 & 99.95 & 99.86 & 99.42 \\
\hline $\mathrm{X}^{-} \pm \mathrm{SD}$ & $99.94 \pm 0.63$ & $100.43 \pm 0.41$ & $100.39 \pm 0.52$ & $99.62 \pm 0.37$ \\
\hline \multirow[t]{5}{*}{ Bastab $^{\circledR}$ tablets containing $20 \mathrm{mg}$ ebastine/tablet } & Ebastine $(0.8 \mu \mathrm{g} / \mathrm{ml})$ & Ebastine $(0.3 \mu \mathrm{g} / \mathrm{ml})$ & Ebastine $(0.1 \mu \mathrm{g} / \mathrm{ml})$ & Ebastine $(0.5 \mu \mathrm{g} / \mathrm{ml})$ \\
\hline & 100.12 & 100.65 & 100.45 & 99.12 \\
\hline & 100.36 & 100.22 & 100.68 & 99.54 \\
\hline & 99.21 & 99.87 & 99.06 & 99.35 \\
\hline & 99.85 & 99.54 & 99.54 & 100.24 \\
\hline $\mathrm{X}^{-} \pm \mathrm{SD}$ & $99.89 \pm 0.61$ & $100.07 \pm 0.48$ & $99.93 \pm 0.76$ & $99.56 \pm 0.48$ \\
\hline \multirow[t]{5}{*}{ Evastine $^{\circledR}$ syrup containing $5 \mathrm{mg}$ Ebastine $/ 5 \mathrm{ml}$} & Ebastine $(1.0 \mu \mathrm{g} / \mathrm{ml})$ & Ebastine $(0.4 \mu \mathrm{g} / \mathrm{ml})$ & Ebastine $(0.2 \mu \mathrm{g} / \mathrm{ml})$ & Ebastine $(0.6 \mu \mathrm{g} / \mathrm{ml})$ \\
\hline & 100.98 & 100.65 & 100.54 & 99.65 \\
\hline & 100.45 & 100.15 & 100.98 & 99.15 \\
\hline & 99.32 & 100.98 & 99.48 & 100.54 \\
\hline & 99.15 & 100.11 & 99.72 & 100.32 \\
\hline $\mathrm{X}^{-} \pm \mathrm{SD}$ & $99.98 \pm 0.88$ & $100.47 \pm 0.42$ & $100.18 \pm 0.7$ & $99.92 \pm 0.64$ \\
\hline
\end{tabular}

Table 7 Determination of ebastine in its dosage forms using method I

\begin{tabular}{|c|c|c|c|c|}
\hline Parameter & $\begin{array}{l}\text { Amount taken } \\
(\mu \mathrm{g} / \mathrm{ml})\end{array}$ & $\begin{array}{l}\text { Amount found } \\
\qquad(\mu \mathrm{g} / \mathrm{ml})\end{array}$ & \% Recovery & Comparison method ${ }^{3}, \%$ Recovery \\
\hline \multirow{7}{*}{$\begin{array}{l}\text { Bastab }^{\circledR} \text { tablets containing } 20 \mathrm{mg} \\
\text { ebastine/tablet }\end{array}$} & 0.1 & 0.099 & 99.71 & 99.23 \\
\hline & 0.2 & 0.199 & 99.52 & 99.61 \\
\hline & 0.3 & 0.301 & 100.33 & 100.61 \\
\hline & 0.5 & 0.503 & 100.62 & \\
\hline & 0.6 & 0.602 & 100.33 & \\
\hline & 0.8 & 0.798 & 99.75 & \\
\hline & 1.0 & 1.01 & 100.64 & \\
\hline $\mathrm{X}^{-} \pm \mathrm{SD}$ & & & $100.13 \pm 0.46$ & $99.82 \pm 0.71$ \\
\hline Student's $t$ test & & & $0.27(1.94)^{*}$ & \\
\hline F test & & & $2.38(5.14)^{*}$ & \\
\hline \multirow{7}{*}{$\begin{array}{l}\text { Evastine }^{\circledR} \text { syrup containing } \\
5 \text { mg ebastine } / 5 \mathrm{ml}\end{array}$} & 0.1 & 0.101 & 100.96 & 100.12 \\
\hline & 0.2 & 0.201 & 100.55 & 99.61 \\
\hline & 0.3 & 0.301 & 100.33 & 99.51 \\
\hline & 0.5 & 0.499 & 99.81 & \\
\hline & 0.6 & 0.598 & 99.67 & \\
\hline & 0.8 & 0.801 & 100.13 & \\
\hline & 1.0 & 1.01 & 100.93 & \\
\hline$X^{-} \pm S D$ & & & $100.34 \pm 0.51$ & $99.75 \pm 0.33$ \\
\hline Student's $t$ test & & & $0.34(1.94)^{*}$ & \\
\hline $\mathrm{F}$ test & & & $2.39(5.14)^{*}$ & \\
\hline
\end{tabular}

*Figures between parenthesis are tabulated $\mathrm{t}$ and $\mathrm{F}$ values at $\mathrm{P}=0.05^{35}$. 
Table 8 Determination of ebastine in its dosage forms by SFS using method IIB

\begin{tabular}{|c|c|c|c|c|}
\hline \multicolumn{4}{|c|}{ Proposed method } & \multirow{2}{*}{$\begin{array}{c}\text { Comparison method }^{3} \\
\text { \%Recovery }\end{array}$} \\
\hline Preparation & Amount found $(\mu \mathrm{g} / \mathrm{ml})$ & Amount found $(\mu \mathrm{g} / \mathrm{ml})$ & \%Recovery & \\
\hline \multirow[t]{6}{*}{ Bastab $^{\circledR}$ tablets containing $20 \mathrm{mg}$ ebastine/tablet } & 0.1 & 0.099 & 99.28 & 99.23 \\
\hline & 0.3 & 0.299 & 99.84 & 99.61 \\
\hline & 0.5 & 0.503 & 100.66 & 100.61 \\
\hline & 0.7 & 0.703 & 100.43 & \\
\hline & 0.9 & 0.903 & 100.39 & \\
\hline & 1.0 & 0.998 & 99.77 & \\
\hline $\mathrm{X}^{-} \pm \mathrm{SD}$ & & & $100.06 \pm 0.52$ & $99.82 \pm 0.71$ \\
\hline Student's $t$ test & & & $0.35(2.31)^{*}$ & \\
\hline Variance ratio $\mathrm{F}$ test & & & $1.86(5.79)^{*}$ & \\
\hline \multirow[t]{6}{*}{ Evastine $^{\circledR}$ syrup containing $5 \mathrm{mg}$ ebastine $/ 5 \mathrm{ml}$} & 0.1 & 0.1001 & 100.06 & 100.12 \\
\hline & 0.3 & 0.298 & 99.64 & 99.61 \\
\hline & 0.5 & 0.499 & 99.87 & 99.51 \\
\hline & 0.7 & 0.704 & 100.59 & \\
\hline & 0.9 & 0.901 & 100.11 & \\
\hline & 1.0 & 1.007 & 100.74 & \\
\hline $\mathrm{X}^{-} \pm S D$ & & & $100.17 \pm 0.42$ & $99.75 \pm 0.33$ \\
\hline Student's t test & & & $0.24(2.31)^{*}$ & \\
\hline Variance ratio $\mathrm{F}$ test & & & $1.62(5.79)^{*}$ & \\
\hline
\end{tabular}

*Figures between parenthesis are tabulated $t$ and $F$ values at $P=0.05^{35}$.

Table 9 Kinetic parameters for acidic and alkaline degradation of ebastine using the proposed methods

\begin{tabular}{|c|c|c|c|c|c|c|c|c|}
\hline \multirow[t]{3}{*}{ Temperature $\left({ }^{\circ} \mathrm{C}\right)$} & \multicolumn{4}{|c|}{ Method I } & \multicolumn{4}{|c|}{ Method II } \\
\hline & \multicolumn{2}{|c|}{ Alkaline degradation } & \multicolumn{2}{|c|}{ Acidic degradation } & \multicolumn{2}{|c|}{ Alkaline degradation } & \multicolumn{2}{|c|}{ Acidic degradation } \\
\hline & $\mathrm{K}\left(\min ^{-1}\right)$ & $t_{1 / 2}$ (min.) & $\mathrm{K}\left(\min ^{-1}\right)$ & $t_{1 / 2}$ (min.) & $\mathrm{K}\left(\min ^{-1}\right)$ & $t_{1 / 2}$ (min.) & $\mathrm{K}\left(\min ^{-1}\right)$ & $t_{1 / 2}$ (min.) \\
\hline 50 & $1.06 \times 10^{-2}$ & 65 & $1.3 \times 10^{-2}$ & 52 & $1.06 \times 10^{-2}$ & 65 & $1.3 \times 10^{-2}$ & 52 \\
\hline 60 & $0.94 \times 10^{-2}$ & 74 & $1.2 \times 10^{-2}$ & 58 & $0.94 \times 10^{-2}$ & 74 & $1.2 \times 10^{-2}$ & 58 \\
\hline 70 & $0.89 \times 10^{-2}$ & 77 & $1.1 \times 10^{-2}$ & 62 & $0.89 \times 10^{-2}$ & 77 & $1.1 \times 10^{-2}$ & 62 \\
\hline 80 & $0.81 \times 10^{-2}$ & 86 & $1.03 \times 10^{-2}$ & 67 & $0.81 \times 10^{-2}$ & 86 & $1.03 \times 10^{-2}$ & 67 \\
\hline $\mathrm{Ea}=(\mathrm{Joule} / \mathrm{mol})$ & \multicolumn{2}{|c|}{7.1} & \multicolumn{2}{|c|}{6.8} & \multicolumn{2}{|c|}{6.9} & \multicolumn{2}{|c|}{7.2} \\
\hline
\end{tabular}

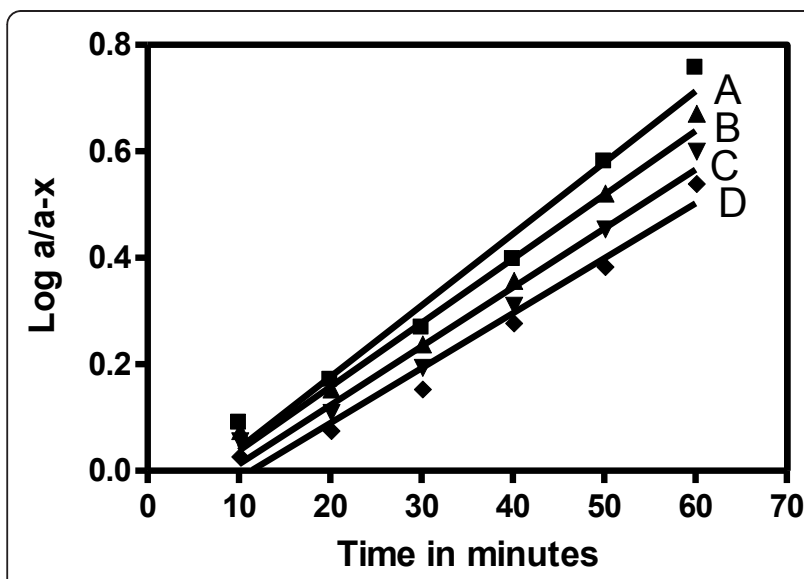

Figure 14 Semilogarithmic plot of EBS $(500 \mathrm{ng} / \mathrm{ml})$ versus different heating times with $0.4 \mathrm{M} \mathrm{HCl} .\left(A=80^{\circ} \mathrm{C}, \mathrm{B}=70^{\circ} \mathrm{C}, \mathrm{C}=\right.$ $60^{\circ} \mathrm{C}$, and $\mathrm{D}=50^{\circ} \mathrm{C}$.

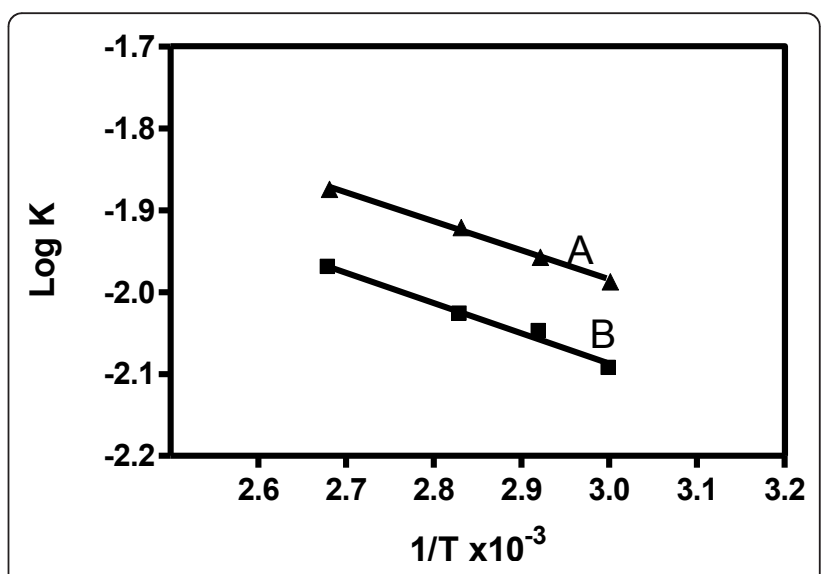

Figure 15 Arrhenius plot for the degradation of EBS using method I. Where: A: (acidic degradation), B: (alkaline degradation). 
Mechanism of the reaction

The stoichiometry of the reaction between ebastine and citric acid anhydride was studied using limiting logarithmic method [36]. As shown in Figure 16, a plot of log RFI versus $\log [\mathrm{CAA}$ ] and $\log$ [ebastine] gave straight lines. The values of the slopes were 0.85 and 1.015 respectively; pointing out that the drug reacts with the fluorigenic reagent in a ratio of 1:1. By analogy to a previous study [37], the reaction pathway is proposed to proceed as shown in scheme 1.Scheme 1

\section{Proposal of the reaction pathway between EBS} and CAA.

\section{Conclusion}

Two validated stability indicating spectrofluorimetric methods were developed for the determination of ebastine (EBS) in pharmaceutical preparations depending on reaction with its tertiary amino group. The simplicity, low cost, and sensitivity of the proposed methods allow their use in quality control laboratories for routine work.
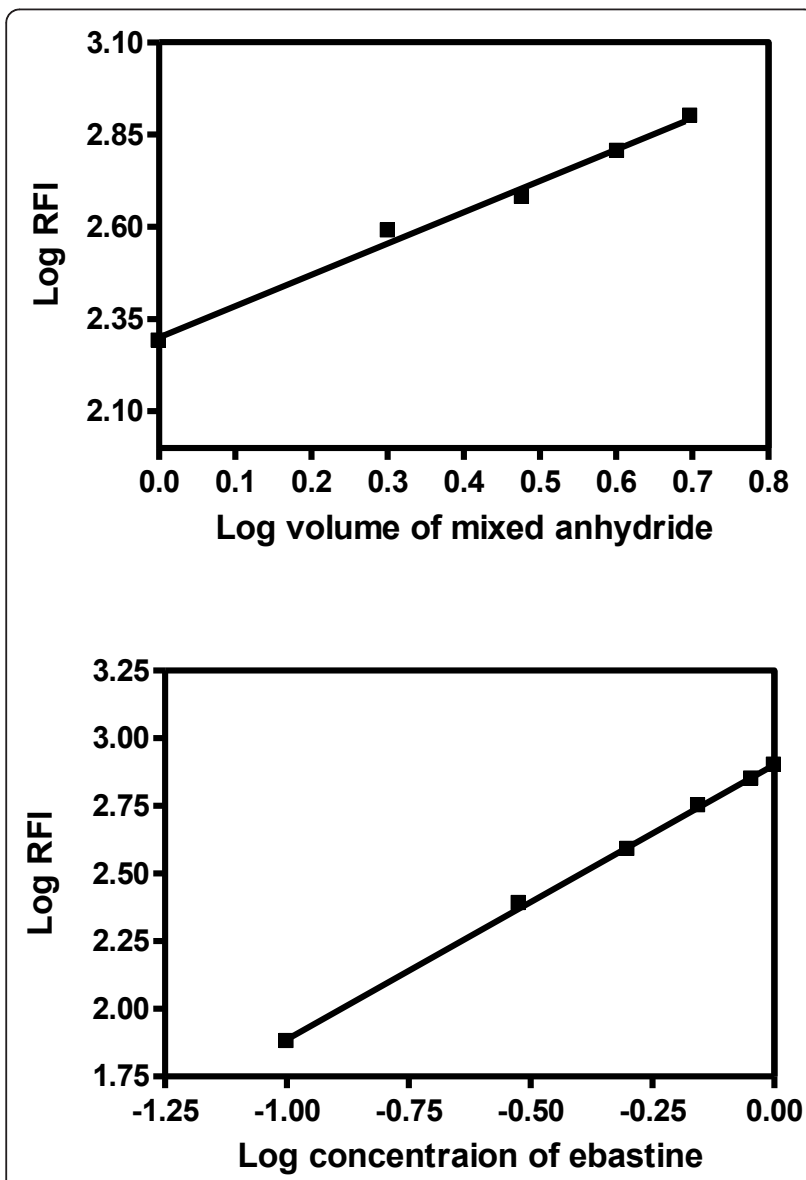

Figure 16 Limiting logarithmic plots for the molar ratio of EBS and CAA.
Acknowledgements

This work was financially supported by Faculty of pharmacy, Mansoura University.

\section{Authors' contributions}

FI designed the proposed method and analyzed the data statistically. MKSE proposed, planned and supervised the whole work. MIE coordinated the study and modified the text. MEKW carried out the experimental work. All authors read and approved the final manuscript.

\section{Competing interests}

The authors declare that they have no competing interests.

Received: 23 December 2010 Accepted: 8 March 2011

Published: 8 March 2011

\section{References}

1. Patai S: The chemistry of thiol group, Part 2. John Willy \& Sons, Inc., New York; 1974.

2. Kang W, Liu KH, Ryu JY, Shin JG: Simultaneous determination of ebastine and its three metabolites in plasma using liquid chromatographytandem mass spectrometry. J Chromatog B 2004, 813(1-2):75-80.

3. Matsuda M, Mizuki $Y$, Terauchi $Y$ : Simultaneous determination of the histamine $\mathrm{H}_{1}$-receptor antagonist ebastine and its two metabolites, carebastine and hydroxyebastine, in human plasma using highperformance liquid chromatography. J Chromatog B 2001, 757(2):173-179.

4. Fiegel F: Spot Tests in Organic Analysis. Elsevier, Amsterdam; 7 1966, 251.

5. Pesez M, Bartos J: Elements de fluorimetrie organique fonctionnelle-II. Talanta 1969, 16(3):331-336.

6. Abdellatef HE, El-Henawee MM, El-Sayed HM, Ayad MM: Spectrophotometric and spectrofluorimetric methods for analysis of tramadol, acebutolol and dothiepin in pharmaceutical preparations. Spectrochim Acta 2006, 65(5):1087-1092.

7. El-Yazbi FA, Gazy AA, Mahgoub H, El-Sayed MA, Youssef RM: Spectrophotometric determination of binary mixtures of pseudoephedrine with some histamine $\mathrm{H}_{1}$-receptor antagonists using derivative ratio spectrum method. J Pharm Biomed Anal 2003, 31(4):801-809.

8. Gazy AA, Mahgoub H, El-Yazbi FA, El-Sayed MA, Youssef RM: Determination of some histamine $\mathrm{H}_{1}$-receptor antagonists in dosage forms. J Pharm Biomed Anal 2002, 30(3):859-867.

9. Mahía PL, Gándara JS, Losada PP, Abuín SP, Lozano JS: Determination of tertiary amines in non-aqueous solvents in the presence of primary and secondary amines. Application to 1:3 BADGE/m-XDA equivalent ratio epoxy-amine formulations. Fres J Anal Chem 1992, 342:581-585.

10. Chen GZ, Huang XZ, Xu JG, Zheng ZZ, Wang ZB: The Methods Of Fluorescence Analysis. Science Press, Beijing, R.P.China; 2 1990, 112.

11. Patra D, Mishra AK: Recent developments in multi-component synchronous fluorescence scan analysis. Trends Anal Chem 2002, 21(12):787-798.

12. Lloyd JBF: Synchronized Excitation of Fluorescence Emission Spectra. Nat Phys Sci 1971, 231:64-65.

13. John B, Soutar I: Identification of crude oils by synchronous excitation spectrofluorimetry. Anal Chem 1976, 48(3):520-524.

14. Aodeng GW, Zhang Y, Fan HY: Determination of metacycline in mixture sample by synchronous-derivative fluorimetry. Guang Pu Xue Yu Guang Pu Fen Xi 2006, 26(8):1530-1532.

15. Karim MM, Jeon CW, Lee HS, Alam SM, Lee SH, Choi JH, Jin SO, Das AK: Simultaneous determination of acetylsalicylic acid and caffeine in pharmaceutical formulation by first derivative synchronous fluorimetric method. J Fluoresc 2006, 16(5):713-721.

16. Wei YF, Li XH, Ma DM: Simultaneous determination of aspirin and salicyclic acid by synchronous fluorescence spectrometry. Guang Pu Xue Yu Guang Pu Fen Xi 2005, 25(4):588-590.

17. Murillo Pulgarin JA, Alanon Molina A, Fernandez Lopez P, Sanchez-Ferrer Robles I: Direct determination of closely overlapping drug mixtures of diflunisal and salicylic acid in serum by means of derivative matrix isopotential synchronous fluorescence spectrometry. Anal Chim Acta 2007, 583(1):55-62.

18. Wang HY, Xiao Y, Han J: Simultaneous Determination of Carvedilol and Ampicillin Sodium by First-Derivative Fluorometry in the Presence of Human Serum Albumin. Anal Sci 2005, 21(5):537-540. 
19. Fernandez-Gonzalez R, Garcia-Falcon MS, Simal-Gandara J: Quantitative analysis for oxytetracycline in medicated premixes and feeds by secondderivative synchronous spectrofluorimetry. Anal Chim Acta 2002, 455(1):143-148.

20. Walash Ml, Belal F, El Enany N, Abdelal AA: Second-derivative Synchronous Fluorometric Method for the Simultaneous Determination of Cinnarizine and Domperidone in Pharmaceutical Preparations. Application to Biological Fluids. J Fluoresc 2008, 18(1):61-74.

21. Walash MI, Belal F, El Enany N, Abdelal AA: Second-derivative synchronous fluorescence spectroscopy for the simultaneous determination of cinnarizine and nicergoline in pharmaceutical preparations. $J$ AOAC Int 2008, 91(2):349-359.

22. Walash M, Sharaf El-Din M, El-Enany M, Eid M, Shalan S: First Derivative Synchronous Fluorescence Spectroscopy for the Simultaneous Determination of Sulpiride and Mebeverine Hydrochloride in Their Combined Tablets and Application to Real Human Plasma. J Fluoresc 2010, 20(6):1275-1285.

23. García-Falcón MS, Simal-Gándara J, Carril-González-Barros ST: Analysis of benzo[a]pyrene in spiked fatty foods by second derivative synchronous spectrofluorimetry after microwave-assisted treatment of samples. Food Addit Contam 2000, 17(12):957-964.

24. Abdelal A, El-Enany N, Belal F: Simultaneous determination of sulpiride and its alkaline degradation product by second derivative synchronous fluorescence spectroscopy. Talanta 2009, 80(2):880-888.

25. Grande BC, Falcón MSG, Pérez-Lamela C, Comesaña MR, Gándara JS: Quantitative analysis of colistin and tiamulin in liquid and solid medicated premixes by HPLC-diode array methods. Chromatographia 2001, 53:460-463.

26. Grande BC, Falcón MSG, Comesaña MR, Gándara JS: Determination of sulfamethazine and trimethoprim in liquid feed premixes by HPLC and diode array detection, with an analysis of the uncertainty of the analytical results. J Agri Food Chem 2001, 49(7):3145-3150.

27. Cancho-Grande B, Rodríguez-Comesaña M, Simal-Gándara J: Simple HPLC Determination of Colistin in Medicated Feeds by Pre-Column Derivatization and Fluorescence Detection. Chromatographia 2001 54:481-484.

28. Rodríguez-Comesaña M, Cancho-Grande B, Simal-Gándara J: Screening method for cross contamination detection of tiamulin residues in swine feeds. J AOAC Inter 2003, 86(3):449-452.

29. Zayas-Blanco F, García-Falcón MS, Simal-Gándara J: Determination of sulfamethazine in milk by solid phase extraction and liquid chromatographic separation with ultraviolet detection. Food Control 2004, 15:375-378.

30. Arias M, García-Falcón MS, García-Río L, Mejuto JC, Rial-Otero R, SimalGándara J: Binding constants of oxytetracycline to animal feed divalent cations. J Food Eng 2007, 78(1):69-73.

31. Guidance for industry; Q2B Validation of analytical procedure: Methodology; International Conference on Hormonization (ICH). 2005 [http://www.fda.gov/downloads/Drugs/

GuidanceComplianceRegulatoryInformation/Guidances/ucm073384.pdf].

32. British Pharmacopoeia Commission: The British Pharmacopoeia. The Stationary Office: London 2007.

33. Fischer $H$, Gottschlich R, Seelig A: Blood-Brain Barrier Permeation: Molecular Parameters Governing Passive Diffusion. J Membrane Biol 1998, 165(3):201-211.

34. United States Pharmacopeial Convention: United States Pharmacopoeia 30; National Formulary 25. US Pharmacopoeia Convention: Rockville, MD; 2007.

35. Miller JC, Miller JN: Statistics for analytical chemistry. Wiley; New York; 2005, 256.

36. Skoog DA, Crouch SR, Holler FJ, Holler FJ, Crouch SR: Principles of Instrumental Analysis. Brooks \& Cole, New York 6 2006:chapter 14:329.

37. Al-Majed AA, Al-Zehouri J, Belal F: Use of mixed anhydrides for the determination of terfenadine in dosage forms and spiked human plasma. J Pharm Biomed Anal 2000, 23(2-3):281-289.

doi:10.1186/1752-153X-5-11

Cite this article as: Ibrahim et al:: Validated stability-indicating spectrofluorimetric methods for the determination of ebastine in pharmaceutical preparations. Chemistry Central Journal 2011 5:11.

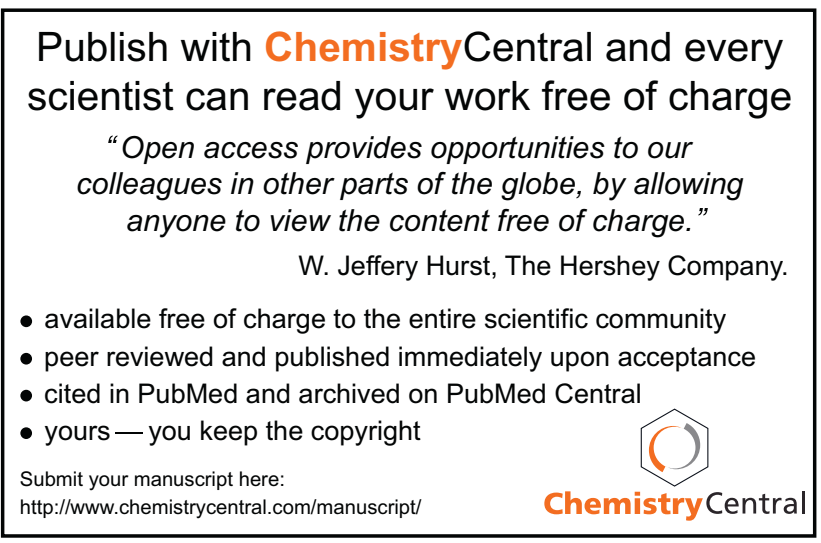

